Vol.1, no.1

EDITORIAL

\title{
Enhancing the Infrastructure of Research on the Nordic Educational Past: The Nordic Journal of Educational History
}

\author{
BJÖRN NORLIN * \\ DAVID SJÖGREN ** \\ (EDITORS)
}

It is with great pleasure that we announce the premiere issue of The Nordic Journal of Educational History (NJEDH), marking the first effort to create a periodical dedicated solely to studies in the educational past of the Nordic region. Before presenting its content, we would like to take the opportunity to provide some basic information and thoughts about the background, scope and underlying concept of the journal.

\section{The Fifth Nordic Conference on the History of Education and the NJEDH}

In September 2012, Umeå University and the Research Group in History and Education hosted the fifth session of the standing Nordic Conference on the History of Education. The theme of this conference was "People, Environments and Media in the History of Education," intending to highlight aspects of the general daily routine of past educative practices in a Nordic context, specifically the interrelation between individuals, educational environments and ways of mediating knowledge. Roughly one hundred participants from throughout the Nordic region and the UK attended the conference, and about eighty presentations were held over the course of more than 20 sessions. The two-and-a-half day gathering offered a wide variety of individual and joint research projects (completed, ongoing or planned), round table discussions and, of course, keynote speeches. The three conference keynotes - addressing issues related to each specific subtheme of the conference - were delivered by Professor Ian Grosvenor, University of Birmingham, UK; Senior Lecturer Charlotte Appel, Roskilde University, Denmark; and Professor Astri Andresen, University of Bergen, Norway. ${ }^{1}$

\footnotetext{
* PhD in History, Department of Historical, Philosophical, and Religious Studies, Umeå University. Email: bjorn.norlin@umu.se.

${ }^{* *}$ PhD in History, Department of History, Uppsala University. Email: david.sjogren@hist.uu.se.

${ }^{1}$ For a full overview of the conference program (including keynote titles, sessions, abstracts and ongoing research projects), see "Femte nordiska utbildningshistoriska konferensen: Människor, miljöer och läromedier (Umeå den 26-28 september 2012)," http://ojs.ub.umu.se/public files/programhafte_2012.pdf
} 
Collaboration between scholars interested in the educational past of the Nordic region has been considerably revitalized over a relatively short period, as evidenced by the number of the joint conferences convened (1998, 2003, 2006, 2009 and 2012). ${ }^{2}$ The durability and high level of attendance of the standing conference underlines its importance as a facility for scientific exchange within this multidisciplinary field. Yet a frequent topic of discussion during the conference in Umeå was the need to further augment the infrastructure of this colloquy. At the final joint session, an initiative was launched to create a web-based journal providing scholars with an additional forum for expanding and improving this growing scientific dialogue.

The first issue of the NJEDH is the result of this proposal, a concrete expression of the last decade of increased Nordic cooperation in the field. Taking on board suggestions made at that closing session, the journal aims to become a high-ranking interdisciplinary periodical. It intends to provide researchers in the history of education committed to studies with particular relevance to the Nordic region and its educational contexts with a portal for communicating and disseminating their research. ${ }^{3}$ Two issues will be published each year, in spring and autumn. The working language will be English, and the publishing languages will be English and the Nordic/Scandinavian languages. The journal will be open for access to all readers, with no fee charged either for publication or subscription, and will apply a double-blind peer review procedure to all submissions.

As regards content, the journal will particularly welcome submissions comprising comparative studies of different parts of the Nordic region. It will strive to publish a blend of articles ranging from doctoral candidate research to manuscripts from more established scholars in the field. Freestanding and conference related issues will be alternated with special thematic issues. Accordingly, the first two issues contain articles from the Umea conference, while the third will be thematically focused on the financing of education and edited by colleagues at Uppsala University. In the near future the journal will also seek to publish book reviews, essays and information about ongoing research projects throughout the region. 4

The Umeå Research Group in History and Education and the University Library at Umeå University will provide administrative management, distribution and technical support for the journal. The journal's editorial board includes leading scholars in the field of educational history, both from within and outside the Nordic region. The members of the editorial board will function as scientific advisors guaranteeing the scientific standards of the journal. The journal also has an editorial staff responsible for the more practical work of editing and publishing. This team will be flexible in order to move effortlessly between university hosts. The editors firmly believe that the primary goal of this new journal is to gain and sustain confidence and credibility within the community of scholars actively researching the Nordic educational past. We are

\footnotetext{
${ }^{2}$ A brief historical overview of the Nordic conferences and research collaboration is provided by Donald Broady, Esbjörn Larsson and Johannes Westberg, "Utbildningens sociala och kulturella historia: En översikt," in Utbildningens sociala och kulturella historia: Meddelanden från den fjärde nordiska utbildningshistoriska konferensen, ed. Esbjörn Larsson and Johannes Westberg (Uppsala: Uppsala University, 2010). The conference has gradually established itself as a genuinely Nordic forum.

3 In the present context, the "Nordic region" refers to the nation-states of Denmark, Finland, Iceland, Norway, Sweden and political and geographical entities including the Faroe Islands, Greenland, Sápmi and the Åland Islands.

4 The NJEDH works in close collaboration with the Nordic Network of Educational history. For more information about the network, please visit: http://utbildningshistoria.se/
} 
therefore grateful for any suggestions or advice that might help us improve it as it grows. 5

\section{Nordic Educational History}

The Nordic Conference on the History of Education and the NJEDH are complementary efforts to encourage transnational and transregional approaches to the study of past educational practices in the Nordic area, thereby generating a common body of knowledge in the field. This being said, the journal's promotion of and dependence on yet another geo-spatial entity, the Nordic, can indeed be criticized as just another effort to tear down old, inward-peering national constructs in order to build "new" ones that are simply more geographically inclusive. Furthermore, the fruitfulness of the concept Nordic as a common analytical hub can be challenged in good conscience. Experiences of education and educational modernization throughout the region have certainly not always followed similar paths, or even paths that are meaningful to one another. In addition to this, the concept is historically burdened. The conception of the Nordic peoples or the Nordic periphery as a cultural and geographical entity can be traced back to early modern times, when it was often contrasted with more civilized parts of Europe. ${ }^{6}$ When the concept Nordic had its popular breakthrough in the latter half of the $19^{\text {th }}$ century, it served principally as a slogan for transnational cultural engagement among the middle classes, drawing on the notion of a common past as a cultural extension of nationalism, a notion not adopted with equal enthusiasm in the countries involved. During the $20^{\text {th }}$ century, the concept has, for example, been used with reference to the history textbook revision conducted by the Norden Associations, and it is today only one of several overlapping concepts used to dissect and describe factors associated with the northern parts of Europe. ${ }^{7}$

The editors' view of the purpose and scope of the journal is as follows. First of all, and needless to say, we acknowledge that there is indeed a common transnational Nordic experience related to the educational past, making Nordic a joint concept relevant to the field. Just as relationships between nation-states and modernization processes are historically intertwined in a range of areas, so is the case when it comes to education. ${ }^{8}$ This refers not only to the construction of educational systems, pedagogical influences or cooperation as regards content, but on a more profound level, to the geographical premises for the conduct of schooling - with extensive parts of the region being vast and sparsely populated, culturally mixed and multilingual, etc. - and of schooling in times when the borders of these nation-states regularly fluctuated. Other common denominators are the robust Lutheran heritage and the powerful influence of national churches on education, as well as the shared colonial experiences vis-à-vis respective northernmost regions, where the role of education has been central for managing relationships with indigenous peoples and other minority groups. This

\footnotetext{
5 Contacts and information about the journal are available at the web portal: http://ojs.ub.umu.se/index. $\mathrm{php} / \mathrm{njedh}$

${ }^{6}$ Cf. Olaus Magnus, Historia de gentibus septentrionalibus (1555).

7 Cf. Øystein Sørensen and Bo Stråth, eds., The Cultural Construction of Norden (Oslo: Scandinavian University Press, 1997); Max Engman and Åke Sandström, eds., Det nya Norden efter Napoleon (Stockholm: Almqvist \& Wiksell International, 2004); and Henrik Åström Elmersjö, Norden, nationen och historien: Perspektiv på föreningarna Nordens historieläroboksrevision 1919-1972 (Lund: Nordic Academic Press, 2013), chapter 3.

8 Cf. Sirkka Ahonen and Jukka Rantala, eds., Nordic Lights: Education for Nation and Civic Society in the Nordic Countries, 1850-200o (Helsinki: SKS Finnish Literature Society, 2001).
} 
has caused tensions still being felt today. The educational systems in the postindustrialized Nordic region are now facing similar challenges due to globalization, high youth unemployment, increasing levels - and increasing awareness - of multiculturalism, and so on.

With these past and present similarities in mind, it can nonetheless be argued that nowadays, the differences are becoming more apparent than ever before. Widely divergent political interpretations of historical experience are paving the way for increasingly diverse solutions in the educational sector (e.g. decentralization and privatization), an ongoing transformation that itself poses a formidable task to historical research.

It is the editors' belief that these shared Nordic experiences can be most beneficially addressed through close interaction between researchers concentrating on as many different regions as possible. So naturally, the NJEDH is not a journal dedicated exclusively to scholars based in the Nordic region, but to scholars and readers throughout the world interested in the educational past of the Nordic geographical region.

As regards educational history, the editors are hesitant to set down a fixed definition of the concept. Our view is that the very process of negotiating its parameters is situated at the core of the subject and that it is the prerequisite of each individual study to define its own significance and position in relation to specifically perceived aspects of the field. However, we would like to provide prospective authors with a broad notion of our understanding of the concept. The journal understands educational history as the historical study, irrespective of disciplinary affiliation, of topics related to the diverse range of human practices aimed at framing, planning and transmitting cultural and social heritage (knowledge, skills, values, behavioral patterns, social relationships, etc.), as well as the ideological, linguistic, material, spatial, visual, emotional and sensory conditions these practices require or sustain. This naturally also includes individual or collective experiences of such practices.

\section{Our Debut Issue: Authors and Articles}

The first issue of the NJEDH contains four articles originally presented as papers at the fifth Nordic conference in Umeå. The papers have been revised to meet the scientific criteria of the journal and been subjected to a double-blind peer review process. In the opening article, Professor Ólöf Garðarsdóttir and Emeritus Professor Loftur Guttormsson of the University of Iceland in Reykjavik investigate the demographic and social characteristics of the teaching corps in Iceland between 1930 and 1960, relating their findings to existing knowledge on the modernization of the teaching profession. The study compares urban and rural areas as well as different school types and reveals considerable differences in the social profile of teachers. The article also provides new demographic evidence that the professionalization of teaching occurred much earlier than previously known in an Icelandic context.

In the second article, doctoral candidate Kristina Ledman of Umeå University, Sweden, presents an analysis of the role of general (academic) subjects in the curriculum for practically oriented education and training in Swedish upper secondary schools after the Second World War. She demonstrates how the inclusion of general subjects in vocational education was motivated in policy debate and influenced by shifts in political leadership. The article provides new, specific insight into central 
aspects of policy work and political negotiation and on a more general scale, into the constantly transmuting views on general subjects and their ascribed social value in the Swedish educational context.

Professor Liv Helene Willumsen of the University of Tromsø, Norway, examines the establishment of the first government-financed Norwegian teacher-training institute in the third article. Founded in the 1820 s, the role of Trondenes Seminarium was to promote schooling for Saami and settler children in the northernmost reaches of the country. In her study, Willumsen provides insight into the interplay between central and regional authorities, as well as between the state and the church during this early period in the development of the Norwegian primary school system.

Finally, Professor Christian Lundahl of Karlstad University, Sweden, examines the role of standardized testing and international precedent in the process of national curriculum change. Lundahl clarifies how representatives of the Swedish progressive movement used its participation in the International Examination Inquiry (IEI) in the 1930s, not so much as a source of ideas or methods to be imported to classroom practice, but rather as a broader experience of urbanity lending credence to the movements' own solutions to perceived national education issues. Participation in the IEI was also used to establish and promote an institute dedicated to the development of psychological and pedagogical research and methods that would come to make a significant impact on the national curriculum.

\section{References}

Ahonen, Sirkka and Jukka Rantala, eds. Nordic Lights: Education for Nation and Civic Society in the Nordic Countries, 1850-20oo. Helsinki: SKS Finnish Literature Society, 2001.

Broady, Donald, Esbjörn Larsson and Johannes Westberg. "Utbildningens sociala och kulturella historia: En översikt.” In Utbildningens sociala och kulturella historia: Meddelanden från den fjärde nordiska utbildningshistoriska konferensen, edited by Esbjörn Larsson and Johannes Westberg. Uppsala: Uppsala University, 2010.

Engman, Max and Åke Sandström, eds. Det nya Norden efter Napoleon. Stockholm: Almqvist \& Wiksell International, 2004.

"Femte nordiska utbildningshistoriska konferensen: Människor, miljöer och läromedier (Umeå den 26-28 september 2012)”. http://ojs.ub.umu.se/public files/programhafte 2012.pdf

Sørensen, Øystein and Bo Stråth, eds. The Cultural Construction of Norden. Oslo: Scandinavian University Press, 1997.

Åström Elmersjö, Henrik. Norden, nationen och historien: Perspektiv på föreningarna Nordens historieläroboksrevision 1919-1972. Lund: Nordic Academic Press, 2013. 